\title{
Cadeias Globais de Valor e Assimetrias de Poder: Uma Análise a Partir da Divisão Internacional do Trabalho
}

\section{Julia Pantin da Silva*, orientador: Lucas Teixeira}

\section{Resumo}

Esta iniciação científica constitui de uma leitura crítica sobre o debate da divisão do trabalho em um sistema internacional, procurando apreender os mecanismos que determinam a distribuição desigual de valor. Tal leitura veio no sentido de explicar a persistência de assimetrias de poder nas Cadeias Globais de Valor, em contraponto a teses difundidas a respeito da possibilidade de integração de países subdesenvolvidos neste novo sistema de organização do comércio.

\section{Palavras-chave:}

Cadeias Globais de Valor, Sistema-Mundo, Divisão Internacional do Trabalho .

\section{Introdução}

A hipótese inicial deste trabalho é a de que, apesar do desenvolvimento recente de novas estratégias de comércio e produção mundiais pela fragmentação da produção em escala global - que origina as chamadas cadeias globais de valor-, persistem assimetrias de poder no sistema interestatal. Assim, ao contrário do que apregoam certas estratégias para cath-up via integração nas cadeias globais, países periféricos ainda enfrentam dificuldades para inserção. Entendendo que tal regionalização e assimetria advêm de distribuições estratégicas de recursos de capital e trabalho, foi efetuada uma revisão bibliográfica acerca do tema, com o objetivo de ver a entender determinantes do fluxo desigual de valor na economia politica internacional. Três visões ganharam destaque nesta revisão:1. a do Sistema-Mundo, com a leitura de Wallerstein e Arrighi; 2.Do Universo em Expansão, de M.C. Tavares e J.L. Fiori e 3. Medeiros e Trebat (2007) em que expõe a economia politica mais recente das cadeias globais.

\section{Resultados e Discussão}

Para Arrighi e Wallerstein, as cadeias de commodities existem desde o início do capitalismo, e se desenvolvem ciclicamente com a economia. A acumulação de capital seria condicionada por um sistema de trocas desiguais que permite a concorrência entre diferentes estados por maiores lucros e vantagens econômicas. Neste sentido, dois elementos do sistema internacional são destacados, estando conectados por uma divisão internacional do trabalho: a) uma economia-mundo dividida entre centro e periferia e b) um sistema de poder interestatal que consolida estas trocas por meio do monopólio da violência. Estabelecidas as trocas desiguais, centro e periferia tendem a se reforçar mutuamente a partir um processo de concorrência que se conforma em causação circular cumulativa, no qual os primeiros acumulam as vantagens de capitais necessárias para remuneração destas atividades, enquanto os países periféricos e semiperiféricos arcam com os custos de remuneração das atividades exploratórias. Com isto tem-se a determinação de hegemonias (estados que consolidam poder econômico a partir da força bélica), que estariam presentes inclusive nas cadeias globais de valor, mantendo a lógica exploratória acima descrita pela distribuição desigual de renda e recursos do trabalho.
A tese de Fiori e Tavares agrega ao debate ao mostrar que a consolidação hegemônica não é condicionada apenas pelo exercício de atividades econômicas, mas também por mecanismos mais sutis de dominação, como a instauração de um sistema monetário hierárquico internacional. Ao conceitualizar a lógica de dominação financeira pelos centros, esta tese corrobora para a hipótese inicial deste trabalho, mostrando que um simples catch up industrial não seria suficiente para dirimir as assimetrias internacionais.

O artigo de Medeiros e Trebat (2017) mostra como a divisão do trabalho nas cadeias de valor gera uma lógica de concorrência que limita a distribuição de valor agregado, formando polos regionais onde a renda é concentrada. A regulamentação sobre atividades de comando de cadeia, como desenvolvimento de marca e softwares (ativos goodwill), característica do novo padrão de comércio nas cadeias globais, torna mais custoso o desenvolvimento de patentes e de outros recursos detentores de valor agregado para os países em desenvolvimento. Dessa forma, a divisão do trabalho nas cadeias globais assinala e aprofunda a assimetria de poder.

\section{Conclusões}

A leitura atenta destas teses, desenvolvidas ao longo de três décadas fornece uma genealogia da assimetria de poder e divisão do trabalho, além de embasar a hipótese inicial deste projeto, de que o espaço mundial é hierarquizado, de tal forma que as cadeias globais não representam apenas vantagens micro e industriais para o catching up, mas antes reafirmam poderes regionais, onde se verifica concentração do valor econômico adicionado.

\section{Agradecimentos}

À atenção de meu orientador que foi um guia neste projeto, e ao apoio financeiro do PIBIC/SAE,o qual viabilizou esta pesquisa

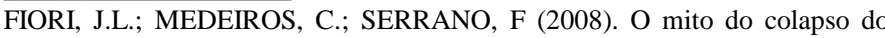
poder americano. Rio de Janeiro: Editora Record.

HOPKINS, T.K,; WALLERSTEIN, I. Patterns of Development of the Modern World-System. Review (Fernand Braudel Center), Vol. 1, No. 2 (Fall, 1977), pp. 111-145.

MEDEIROS, C. A \& TREBAT, N. (2017) Inequality and Income Distribution in Global Value Chains, Journal of Economic Issues, 51:2, 401-408 